\title{
The Impact of Macroeconomic Factors on Stock Market: An Evidence from China and Pakistan
}

\author{
Isbat Alam ${ }^{1}$, Muhammad Mohsin², Khalid Latif ${ }^{3}$, Muhammad Zia-ur-Rehman ${ }^{4}$ \\ ${ }^{1} \mathrm{PhD}$ Scholar, Department of Business Administration, Liaoning Technical University, Hulodao, \\ China \\ ${ }^{2}$ Department of Business Administration, Liaoning Technical University, Hulodao, China \\ ${ }^{3}$ Assistant Professor, Department of Commerce, GCU, Faisalabad, Pakistan \\ ${ }^{4}$ Assistant Professor, Department of Management Sciences, NTU Faisalabad, Pakistan
}

\section{A B S T R A C T}

Silk Road is an ancient strategy of economic and trade routes development network between emerging and developing economy (China \& Pakistan). The main purpose of this research is to empirical inspect the association exist among the China stock exchange (SSE), Pakistan Stock Exchange (KSE-100) with macroeconomic variables (Gross Domestic Product, Balance of Trade, Foreign Direct Investments, Lending interest rate and Money Supply). The annual time series data from 1995 to 2019 used to find out the results. Macroeconomic variables have an essential role in any changes in every economy. Any unexpected variations amongst these variables influence the economy in several ways. Multiple regression techniques were analysed and examine for the significance of data to approximate the probable impacts of variables on stock market prices. Breusch Godfrey Serial Correlation with heteroskedasticity assessment is utilized to investigate the correctness as well as residual normality of series data. The finding of this study exposed that GDP is negative significant $10 \%$ with SSE and $1 \%$ at level with $\mathrm{KSE}$, FDI is insignificant with SSE. negative significant $10 \%$ at level with KSE and the result of BOT shows positive significant $5 \%$ at level with SSE while insignificant with $\mathrm{KSE}, \mathrm{M} 2$ is significant $5 \%$ at level with SSE but insignificant with KSE and LI are shown statistically significant $1 \%$ at level with SSE While positive significant $10 \%$ with KSE. It is determined that it is significant and an insignificant relationship among the variables with both stock markets returns. The financial analyst, policymaker appreciate these findings, investors, shareholder, stock exchange editors, security exchange supervisors as well as for the Government.

Keywords: Macroeconomic variables, Shanghai Stock Exchange, Karachi Stock Exchange

\section{INTRODUCTION}

Stock exchange is a place where buying and selling of security (bonds and 
shares, etc.) are dealt. Stock exchange similarly assists the financials instrument renovation of security and additional issues. Stocks prices also inspire the household decision to make more savings and to contain wealth. Stock markets play a significant role for nation's economic system since shifting of money and bringing together the savers and investors to increase the growth of the economy. Chong and Goh (2003) Indicate right information about stock prices helps the investors and decrease levels of threat and increase profit maximization. According to Fama (1970), the market is hypothetically stated that stock must contain prices and all related information containing accessible public information. Market indexes are utilized to evaluate every function of the portfolio and also deliver an indication of the forthcoming tendencies of the market. According to Schirm and Aggarwal (1992). Basic modification to the structure of macroeconomic and policy that played a vital role in financial reliability achieving can be discreet to the new growing stock market of the country. Stock market helped as a third party business organized assets transfer from stockholder to the investors in exchange for possession shares are an essential part of the open market economy. Since Mukit (2012) investigate that borrower call for possessions after a parallel frame through the prospect that will be mandatory to reimburse the full amount with the financing charge in upcoming. According to Arbitrage price theory (APT) developed by Ross (1976), Chen et al. (1986) discuss specific macroeconomic Factors to describe stock return in the US market. According to them, when industrial productions variant in the risk premiums, variation in time structures are positively connected to the expectation of return stock. However, this research often has study the possible effect of the macroeconomic variables either on development of the stock market or how understands of this relation help the investors to invest their capital and select the best country for investment for increase their return and avoid the risk that had phase previously. It's mean internationally diversifications can decrease risk. Also, there is a gape in literature when we are selecting two economies of a country to parallel placed in the portfolio. Besides of Walter (1989) the rarer study to look at the prospective profits of significant this association, especially in preparing portfolio when the economic situation in crises. The stock price is prejudiced through fixed of macroeconomic variables similar GDP, FDI, 
BOT and M2 by the way adverse through the interest rate. Security is exchanged the option fund and security exchange. Securities are a trade of reserves. according to Strohe and Achsani (2002), The economic growth is affected by variation in stock prices. When the prices are going up, it shows growth positively in any country of economic activities. Although when the stock prices decrease indicates declined in the economic activities of some country. The study of Fama (1981) cleared that macroeconomic factors activity is strongly impacted the stock price growing and declining. This assumption that mark prices may be occupied for the future of organizations accomplishments. The stock market concerned is not only narrow to strategy maker, and researcher, fairly the relationship among the macroeconomic variables and both stock market factors likewise attract the consideration of capital investor and economist basically of three motives first, policies maker should be intelligent the complete effected of existing and coming rules and principle. Secondly, the investor should be further informing decisions once they completely know this relationship and consequently reduce their Disclosure to threats. Thirdly, if the investors know the variation happened in the economic activities or the stock market the shock factors will be decreased, and the investors will be clever to hold prevention measure Lidah and Harasheh (2011). Effect of the key macroeconomic factors on both stock exchange markets in China and Pakistan, we stay deliberate and compared economic environments for these two countries for the determination of investment. The main motives between China and Pakistan have different environments of the economy. It is must for the investors to have proper information of the distinctive feature of twice economy formerly building normal decisions for his investment.it is true that both economies have different prospects.

\subsection{Karachi Stock Exchange (KSE-100 index)}

Karachi Stock Exchange (KSE-100) one of the oldest, highest and second stocks exchange of south Asian countries and leading stock in Pakistan (PSX). The KSE-100 is one the prominent stock market in Pakistan the investors use as a yardstick for shares price. Which is established since 1947, on that time KSE have five companies are called KSE-50 with an overall market capitalization of $\$ 260,000$ (37 million PKR). There are other two stock exchanges which were established 1974 Lahore stock exchange (LSE) 
and Islamabad stock exchange (ISE) in 1997 individually. Recently study indicates that 80 to $85 \%$ of turnovers arise at KSE-100, which is day-to-day average turnovers of 145 million stocks. Karachi stock exchanges (KSE) encourage capital realization, and assisted a full scale of the participant, containing individually and institutionally investors from the last 73 years. Automated trading system activated, and work from the previous 1990s in 2002 the KSE launch the KATS (Karachi automated trading system), can hand over 1 million trading a day in that year KSE was declared "performance top market in the world" KSE, LSE and ISE stock exchanges were combined the supervision of ACT 2012 of Pakistan stock exchange. With the rising figure of recorded firms and business activities, the KSE-100 index was familiarized in November 1991 with cement, baking sector, E \& P, manufacturing plants, pharmacological and so on. 20th April 2008 for the first time KSE-100 index cross over 15,000 points and touched the entire end of 15,737, it was the $7.4 \%$ of growth and Pakistan stock exchange become emerging market rest of the world (Bårdsen et al., 2005; Driehuis et al., 2014; Den Butter, 1991). In 2008 stock exchange was prejudiced by inflation, interest rate, attack by irritated investors on KSE building, President Pervez Musharraf resignation and challenges of Taliban. PSX once improve all the neglected of 2008 covered in 2009 and once again become the best third stock exchange rest of the world. In June 2015, 26\% equities transported for US dollar and maintain the top-performing positions all over the world stock exchanges. In 2016 Karachi stock exchange indicates an upward tendency, the investors confidentially invest in PSX. The KSE shows from 2017 to 2019 in these three years performed a mixed viewpoint.

\subsection{Shanghai Stock Exchange (SSE)}

Volatility from the forty years' stock market of China has been locked the Mao Era meanwhile. Afterwards, the culture revolutions sequence improvements and implementation, finally in November 1990 Shanghai stock exchange (SSE) was regenerate marked the opening of the stock market under the Administration of Peoples Republic of China (PRC). On 1st December 1990, Shenzhen Stock exchange (SZSE) was originated. The SZSE and SSE both become the stock markets of china.2001 to 2005 in four years' stock market crash SSE go halves on, after 2001 a sanction on initial public 
offering (IPOS) in 2005 to control these slumps besides permit further USD 200 billion of state-owned equities for trade share converting. The SSE restarted complete operations in 2006 as the yearlong bans on initial public offering (IPO) were lift in May and the world-leading second (\$21.9 billion) IPOs launch for both Hong Kong and Shanghai stock exchange by industrials and commercial bank of china (ICBC). 16 October 2007, SSE (stock market frenzy) reached to peak with 6,124.044 points become the world's second-largest stock turnover but med of 2008 decrease to $65 \%$ causes of global economic crises. The total stock value of SSE and SZSE stock exchanges are reached to 3.3 trillion USD dollar in 2011, regarding that the stock exchange is younger and in the trading environment. Many listed companies in the stock market have become a subsidiary of state-owned monopolies (Hairault \& Kempf, 2013; Chirichiello, 2000; Perkins, 1997). The Government of china constitute a numeral of restricted laws and regulation to control the operation market. Therefore, it is hardly too said the Chinese stock market is compelling. In November 2018 SSE market capitalized USD 4.0 trillion and became 4th leading stock exchange rest of the world. In the 20th last year's Chinese stock markets very developed, introduce the star market even SSE open a NASDAQ type's board of exchanging technology for high growth in 2019. China and Pakistan Silk Road is an ancient trade routes strategy of economic development network hope of peaceful future and economic growth between merging and developed economy. To increase the trade volume, both countries have to introduce the CPEC has a positive impact on neighbour countries and region with expands capacity of trade with the ancient world. The present study attempts on the evidence of the earlier conclusion and inspecting the global linkage of variables with the stock market from both developed and emerging economies. This study has numerous differentiate features. First, the data samples include are more recently, which is ended in 2019 annually. Second, two different economies of merging and developed communicate with Silk Road as a trade route rest of the world.

\section{LITERATURE REVIEW}

Literature review has significance and vital recognized background of the study 
existing conduct. Similarly, it's provided with the solution of the problems and eliminates the prospect of unnecessary recurrence of the determinations. In adding, valuable material on research skills is found from the preceding explanation. The major objectives of this segment are to measures the interrelated literature review. The association between the macroeconomic variables and stock return is a significant part of research marked by various researchers domestically and globally. The effective market hypothesis was defined by Fama (1970). Are an effective market, the past and present information other growing of macroeconomic variables completely impacted in the stock market the investors incapable in making some valuable exchanging rules according to this material (Mussa \&Savastano, 1999; Nelson, 1996; Hall \& Henry, 2014; Fontana \& Setterfield) observed the effect of macroeconomic factors on stock markets. This study recognized the cointegration between macroeconomic factors and the stocks market. Chen et al. (1986) indicate the variations in macroeconomics and stock markets factors ensure a long-standing relationship. Fama $(1981,1990)$ identified the strong positive association between stock return and macroeconomic variables. Ali et al., (2008) Also Studies the relationship of economic growth with stock markets improvement in the study of Pakistan economic development. Capture time series annually data from 1971 to 2006. That the results show their long term relationships among stock market prices with economic growth of Pakistan. Robert and Gay (2016) Indicates the relation of macroeconomic variables with stock market return affected four developing economies China, Brazil, India, and Russia. Use time-series data results are insignificant, which ascertains inefficiency in markets. Fazal and Tariq (2001) Studied the relationship of macroeconomic factors with the stock market prices. The analysis of correlation recommended low correlation occur result shows long-run presence relation between variables and stock price. The study of Levine and Sara (1996) article contain positively relationship between stocks and economic growth since destined factors. Mehrara(2006) Examined the association macroeconomic factors with the stock markets in Iran. Argue that variation is essentially a link to variables; therefore, the changes in stock prices pause behindhand their economic activity. Ahmad et al., (2011) explain the manipulating variables the GDP, money supply, interest rate and balance of payment. That concern 
among them, which eventually clues to money appreciation. The development of the economy can be measure by real growth of GDP, and other key variables determine the growth of the economy. The stock prices impact the economic fundamental; the stock prices working is the principal indicators of economic activities in future Pal and Mittal (2011). Levine and King (1993) Examined frequently the money measurement indicator and scope relevant important of banking sectors. They originated a significantly and positively relation among economic development factors and GDP growth per capita. Al Shabib et al., (2012) inspected the effects of the macroeconomic variables, variation is an independent variable in investments and GDP with the movements of the Amman stock exchange as the variable of dependent for the period of 1990 to 2009. They founded the relation among the GDP and investment with the stock exchange, also with others and individually with the stock index. It means that variation in the prices of the stock exchange market is influenced by the variations of investment and GDP, that influence of the variables toward the stock exchange index movements. Therefore, they examined the impacts of investments fluctuation on the stock index are greater than GDP. Fratzscher and Strub (2010) Discuss following the wealth effect channel, increase in the stock price, particularly if it is deliberately stable, increase the estimated income of the household and thus consumptions, although for a firm at ease to financial investments openings, hence persuading a deterioration in a particular country's trade balance. To study Tiwr et al., (2015) the vibrant correlation of stock prices and trade balance on the USA for the period of 1792 to 2013. The outcomes of our experimental examinations, which remain strong to substitute descriptions, expose that the correlation is not continual, but change heterogeneous ultimately. In exact, the correlation is common, significant positively from 1800 to 1870 , although significant negatively afterwards. Simo-kengne et al. (2015) examine the influence of stockholder, and stock value on US consumptions use from 1890 to 2012, commonly, the stock price effect positive while housing prices negative. I generally when the stockholder draws their capital when the stock market during the boom conditions for increases their capital investments and decrease their consumptions. Therefore, the capital affected by decreases or increases of consumption, hence deterioration or refining trade balance. Aggarwal and Schirm, 1992 and 1998, examine 
the trade balance and stock price, which affected each other, either correlated with negatively or positively dependent, which on impacts. Raza et al., (2012) used the OLS technique of regressions take time-series data annually from 1988 toward 2009 of Pakistan to evaluate the realistic associations amongst variables stock market. Fined the positive impacts of FDI with Pakistan stocks market. Schmukler et al., (2001) examined the foreign direct investment take data from 1975 to 1999 taken eight variables as a model and applying regression methods. They founded that FDI has strong positive relations with stock market developments. Evaluate whether the FDI is substitute stock markets developments in a country that is further risk and economically undeveloped or whether the FDI are more attractively individual to overcome the stock market through the barrier of investment. Gilani et al., (2010) Attempt the period of 1985 to 2008, to finds the stock markets relation with foreign direct investment during their study they found significance positively relationships between economic growth and FDI. Alam and Uddin (2009) Examined significant relationships between the rate of interest and stock prices collect data of 15 developed and non-developed countries from 1988 to 2003. Inspect inefficient market, relationships between stock prices rate of interest and, variations of the stock price, and variation in the rate of interest was determined by together panels regression and time series. The result indicates that the relationships of interest rates have significance negatively with stock price and found variation in interest rates has significance negatively relationships with a variation of stock prices. A monetarist's opinion of relationships between stock prices and rate of interest. The studies mostly allocated with the supply of money and stock market prices. As increasing in the supply of money decline the interest rate and when the supply of money reduces the rate of interest rise. The study for the period of 1918 to 1968 on the USA, out of 12 large markets nine markets smash downcast during the commercial constructions variations supply of money affect the stock price to fall down and finally the rate of interest. Trivoli and Bulmash (1991) Recognized that interest rates have negatively impacted the stock price. The highest rate of interest influences further techniques of investment. Martin (2012) Dignified supply of money by broad money M2 and cumulative money with zero maturity (MZM). This study objective is to identify, if this 
money supply influences the stock indices in the duration of 1967 to 2011 if the effects of both moneys collectively are nearby the similar and in what way supply of money impact the bubble conception. Masky (2007) is also discussing that the anticipated and nonanticipated variations in the supply of money impact the stock markets inversely. Changing impacts of anticipated and non-anticipated supply of money on stock markets. Furthermore, Mookerjee and yu (1997) examined that supply of money has a long-run relationship with stocks price in Singapore. Peebles and Wilson (1996) Specified when an appreciation occurs in money, and it is normally escorted by rises in funds, money supply decrease in the rate of interest. In conclusion, the budget of money and import input decrease, foremost to increase in native equities returns. Jawad and Hasan (2009) Explained long term relationships between the monetary variable and equities pricing for the dated 1998 to 2008 . Outcomes show that stock price was the negative relay.

\begin{tabular}{|c|c|c|c|c|}
\hline Variables & Perception & Explanation & Units & Sources \\
\hline SSE & $\begin{array}{l}\text { Shanghai Stock } \\
\text { Exchange }\end{array}$ & $\begin{array}{l}\text { SSE composite } \\
\text { Index }\end{array}$ & $\begin{array}{l}\text { Composite Share } \\
\text { Price RMB }\end{array}$ & $\begin{array}{l}\text { Investing.com, } \\
\text { yahoo finance }\end{array}$ \\
\hline KSE & $\begin{array}{l}\text { Karachi Stock } \\
\text { Exchange }\end{array}$ & KSE 100-index & $\begin{array}{l}\text { KSC } 100 \text { Index } \\
\text { Price in RS. }\end{array}$ & $\begin{array}{l}\text { Karachi stock } \\
\text { Exchange official site }\end{array}$ \\
\hline GDP & $\begin{array}{l}\text { Gross Domestic } \\
\text { Product }\end{array}$ & $\begin{array}{l}\text { Level of economic } \\
\text { Development }\end{array}$ & GDP Per Capita & $\begin{array}{l}\text { World Development } \\
\text { Indicator }\end{array}$ \\
\hline BOT & Balance of Trade & $\begin{array}{l}\text { Export minus } \\
\text { Import }\end{array}$ & Percentage of GDP & $\begin{array}{l}\text { World Development } \\
\text { Indicator }\end{array}$ \\
\hline FDI & $\begin{array}{l}\text { Foreign direct } \\
\text { investment }\end{array}$ & FDI inflow & Percentage of GDP & $\begin{array}{l}\text { World Development } \\
\text { Indicator }\end{array}$ \\
\hline LI & $\begin{array}{l}\text { Lending Interest } \\
\text { Rate }\end{array}$ & $\begin{array}{l}\text { Percentage of } \\
\text { Interest rate }\end{array}$ & $\begin{array}{l}\text { Percentage of } \\
\text { Lending Interest Rate }\end{array}$ & $\begin{array}{l}\text { World Development } \\
\text { Indicator }\end{array}$ \\
\hline M2 & Money supply & Broad money (M2) & $\begin{array}{l}\text { Money Supply in } \\
\text { RMB/Rupees }\end{array}$ & $\begin{array}{l}\text { Business recorder, State } \\
\text { Bank of Pakistan }\end{array}$ \\
\hline
\end{tabular}

\subsection{Collection of Data}

This study of research is founded on secondary base data. The collections of data are time series annually for the period of 1995 to 2019 (25 years). After the consulting and studying the reviewing as well as literature both economies, it's deliberate that eight 
macroeconomic variables are important to check both relationships with stock price and as well as the empirical and their theoretical explanation. The above mention sources of data have been choosing for the reason that most reliable and used by the researcher. The data required various arrangement tools and directly downloaded to excel file. Our plus point is that our data is frequently updated. The next study describes the research hypothesis and the variables through which methods and strategies are developed.

Research variables one is dependent, and five have become independent variables. In this research, the dependent variables are the stock market of Pakistan KSE and China stock market SSE. In-dependent variables are Gross domestic product, the balance of trade, foreign direct investments, lending rate of interest, and money supply.

A. The stock market stock exchange is a stock market which deals with buying and selling of securities. Barket et al., (2016) According to the previous study that stock market helps who are showing interest in stock market whichever the investor, academics, or government officials stock market index are designed as a tool in demand to be capable of assessing the conclusion of investment advisor and portfolio manager. The index movement measures the performances of the stock market. In the economic indexes, the collections of the key firms stock. The study of Barket et al., (2016) also concluded that index fluctuation is affected through global variables and firm, precise variable macroeconomic social and political. This study also helps the investors to take the correct decision according to their hedge and investment against the instability in the stock market According to Jawad and Hasan (2009) the previous work also support the market stock and macroeconomic variable have associations with each other. This study determines also support both the public and Government to anticipate the influences in the stock market. Fazal and Tariq (2001) examine the relation between stock price and variables. The study of Park (1997) indicate that when stock returns extraordinarily defiantly impact by working improvement and prejudiced through GDP. Study of Adam indirect the structures of stock trade are signed to change by macroeconomic variables.

\section{B. Lending interest rate ( $\mathrm{Li})$}

In this research, we used the real interest rate as a proxy rate of interest. The real rate of interest is the almost nominal rate of interest minus rate of inflation. According to 
Hsu et al., (2013) Interest rate is that rate of interest which is paid by the debtor to the lender against the use of money. The previous study determined that different researcher used different interest rate. Barket et al., (2016) this previous study assigned assumed that stock price and rate of interest has a negative relationship. When the bank deposit rate increase, the publics will forward their money to the bank from money market this will cause to decline the shares demand. When the deposit rate decrease, the opposite will occur. Hayat \& Abdullah (1993) examine that interest rate response negatively on stock return.

\section{Gross Domestic Product (GDP)}

The GDP is regarded all of them the most determination element of the performances of stock market measurement is also used for the real economic growth and activities. The result indicates that in the economy when the GDP raised it to determine assist the stock market to rise and boost the stockholders confident upward, through the developing economies. GDP is one of the utmost vital factors in the economy which investigate the conditions of our economy. it facilitates the investor's decision and companies about their strategy they should accept the right effectively decision and policy acceptant. Where Pakistan is a developing country, its GDP is $\$ 1357$ per capita. As compare to china have per capita GDP is 10,263.741 USD in 2019. According to Pooja and Giri (2017), the Real term usually calculates the economic growth, i.e., the inflation-adjusted relations is to eradicate the distortion effected of inflation upon the prices of goods production. The study of Levine and King (1993) is the first who addressed the relationship amongst the economic growth and financial developments the usage of across country context. It conservatively measures the rate of percentage increases in the real GDP. This result is relatively strong across the country of period Levine and Beck (2004) these relations amongst the economic growth and stock price has also been studied through (Fama,1990; Ainous, 2018; Henry, 2013; Barbiero et al., 2019).

\section{Foreign Direct Investment (FDI)}

FDI is the primary and recognizes major foundations for the developing of the economies. In general words, FDI is the inflow of capital, transfer and facilitate the skills, 
managerially and organizationally practice accesses to the global markets and skill. To accesses, the inflow of foreigner capitals is the impacts of that we take the foreign direct investments (FDI). The study of some research papers that FDI has some negatively and significantly effect on the capital Ahmed et al., (2012) however, another study founded that FDI has the impact on the stock market is positively and significantly Adam and Tweneboah (2008) and Ahmad et al., (2012). Foreigner investments drive up the secondary markets. In Pakistan, foreign investments are continually sinking and needed to boost up for the reason that of political instability, effective law and mandate condition

\section{E. Money Supply (M2)}

In this research study we utilized broad money supply as a proxy of RMB and Rupees. M2 is a combination of M1 and less liquid in natures. And also included saving and times deposit, deposit certificate and market money funds. Walter (1989) Discuss that any country stock market is measured to use an aggregate of the monastery. M2 is wider than M1 contain the entire component of M1. In additions, overnights repurchased agreement, overnights Eurodollars, short time and saving, market money and account deposits, and generals purposes dealers fund balance. And also addressed to predict the change in financial/economic activities, interest and inflation rates, the economist needs to study the relation amongst macroeconomics variables and measure of monetary. The previous study of (Reillyand Brown, 2003; Zahra et al., 2020; Pflueger et al., 2020; De Loecker et al., 2020) contended that disequilibrium in the short run demands and supplies of capitals/money influence arise and it determines changed the easiness or stiffness money markets. The narrowing of monetary/capital policy means to decrease the growth rates of the currency supply. The conclusion to change in the equilibriums will push the market. Kochin and Michae (1972), Kraft and Jhon (1977) use money supply (M2) as a proxy supply of money, and they specified the stronger relation amongst M2 and supply of money. Broad money approach is also linked with the stock price, for example, Mukit (2012) he determined that if $1 \%$ change arises interest rate to exchange rates stock prices will affect $1.71 \%$ and $1.04 \%$ correspondingly. Increases in the volume of money will push rise the stock price of companies in the stock exchange. 


\section{F. Balance of Trade (BOT)}

The BOT or equilibrium of goods and services, are the difference amongst export and import. In this study, we take a balance of trade as a measurement of GDP. The relationship between the balance of trade and stock market price either positively or negatively. According to wealth channels, in overall judgment rises in stock price, particularly it is considered as permanent, expect an increase in income of the household and therefore consumption. However, it makes easiest for the substantial investments opportunity, consequently include a declining in a particular country's balance of trade. Fractzcher and Strub (2010) But Ayea et al., (2015) mention that stakeholders withdraw their capital when the market boom to increase their capital investments and therefore reduced their consumptions, then improving the balance of trade. As well as the channels of exchange rate concern, as an increased in the real stock price tend to ensured positively impacts on short-term interests and inflations rate, and clues to an appreciation of the real exchanges rates and also a generous increased in consumptions and the balance of trade Fratzscher and Straub (2009). Therefore, the balance of trade impact on stock price increases in balance of trade beings' inflation leads as a responsive from monetary authorities through high-interest rate, which has negatively influence stock price Hogan et al., (1991). Balance of trade and stock price can affect each other, correlations among the variables either negatively or positively defended on effects.

\begin{tabular}{|c|c|}
\hline Table-2. Variables and their Proxy \\
\hline Variables & Proxy \\
\hline Stock market & Index market \\
\hline Gross domestic products & Per capita \\
\hline Balance of trade & \% of Export -\% of Import of GDP \\
\hline Foreign direct investments & FDI inflow \\
\hline Lending interest rate & Broad money \% of GDP \\
\hline Money supply &
\end{tabular}

The hypothesis of the study:

$\boldsymbol{H}_{0}$ (NULL HYPOTHESIS): there are have no impacts of variables on stock prices. $\boldsymbol{H}_{1}$ (ALTERNATIVE HYPOTHESIS): there are variables that have impacts on stock prices. 
$\boldsymbol{H}_{0}=K S E / S S E$ has no significant relationship with GDP.

$\boldsymbol{H}_{1}=K S E / S S E$ has a significant relationship with GDP.

$\boldsymbol{H}_{0}=$ KSE/SSE has no association with BOT.

$\mathrm{H}_{2}=$ KSE/SSE has an association with BOT.

$\boldsymbol{H}_{0}=K S E / S S E$ has no significant relationship with FDI.

$\boldsymbol{H}_{3}=K S E / S S E$ has a significant relationship with FDI.

$\boldsymbol{H}_{0}=K S E / S S E$ has no association with LI.

$\boldsymbol{H}_{4}=K S E / S S E$ has an association with LI.

$\boldsymbol{H}_{0}=K S E / S S E$ has no significant relationship with $M 2$.

$\boldsymbol{H}_{Z}=K S E / S S E$ has a significant relationship with M2.

\subsection{Conceptual Framework:}

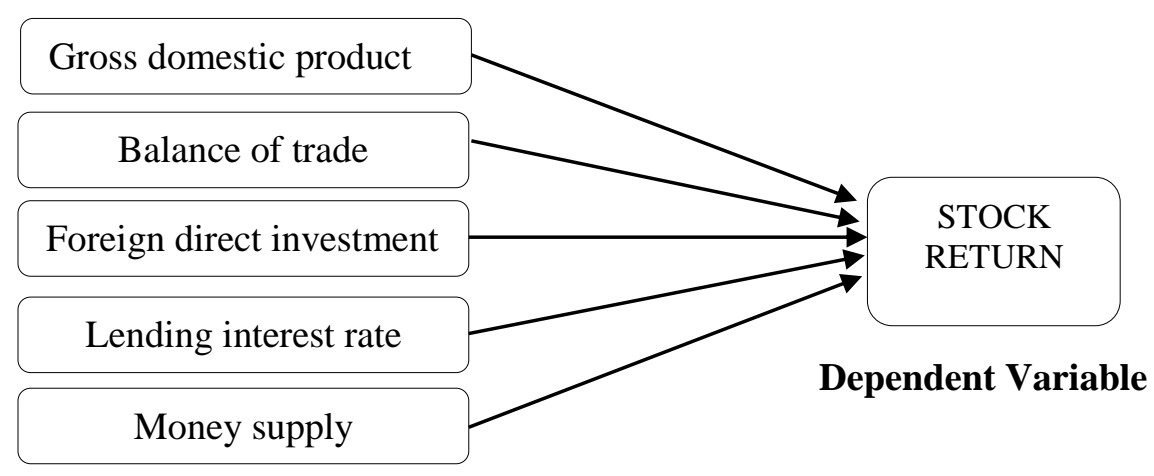

Independent Variables

\subsection{Econometric Model:}

An empirical analysis is conduct through by statistical technique for the study of hypotheses test. Here we used multiple regression and Pearson's product movement correlation coefficient models to search out the key goals of the study.

Multiple regression models of Pakistan

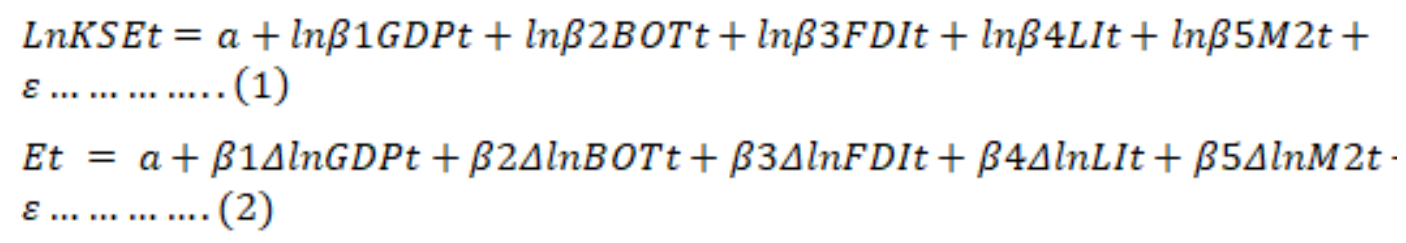


Where KSE-100 index is depended variable (Karachi stock exchange), GDP is independent variable (gross domestic products), BOT is independent variable (balance of trade), FDI is independent variable (foreign direct investment), LI is independent variable (lending interest), M2 is independent variable (broad money supply). The " $a$ " is the KSE100 intercept of $\beta 1, \beta 2, \beta 3, \beta 4$, and $\beta 5$ define the coefficient or slope of the regression equation and " $\varepsilon$ " is standard "error"

Multiple regression models of China:

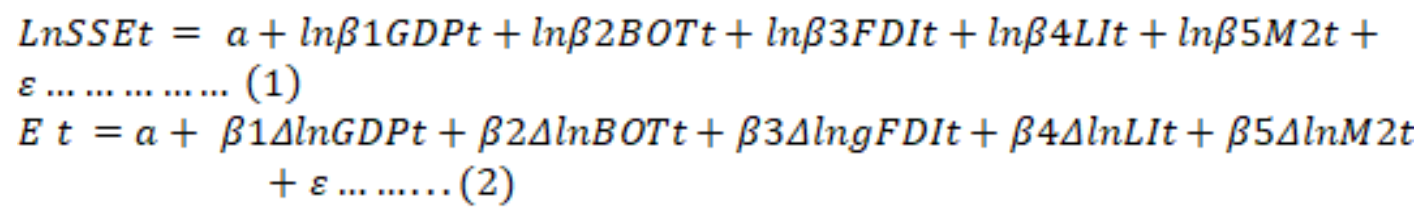

SSE is depended on the variable (Shanghai stock exchange), GDP is the independent variable (gross domestic products), BOT is the independent variable (balance of trade), FDI is the independent variable (foreign direct investment), LI is the independent variable (lending interest rate), and M2 is the independent variable (broad money supply). The "a" is the SSE intercept of $\beta 1, \beta 2, \beta 3, \beta 4$, and $\beta 5$ define the coefficient or slope of the regression equation and " $\varepsilon$ " is standard "error".

\section{EMPIRICAL RESULTS}

\begin{tabular}{|l|c|c|c|c|c|c|}
\hline \multicolumn{7}{|l|}{ Table 3. Descriptive Statistics of SSE } \\
\hline & SSE & M2 & GDP & FDI & BOT & LI \\
\hline Mean & 2213.507 & 160.1618 & 3981.509 & 3.339566 & 3.399398 & 6.0892 \\
\hline Median & 2115.98 & 153.5509 & 2693.97 & 3.513002 & 2.617151 & 5.81 \\
\hline Maximum & 5261.56 & 209.4513 & 10100 & 4.880444 & 8.676234 & 12.06 \\
\hline Minimum & 555.29 & 99.02773 & 609.6567 & 1.367677 & 0.783527 & 4.15 \\
\hline Std. Dev. & 1073.161 & 31.63065 & 3290.105 & 1.085255 & 1.998884 & 1.821343 \\
\hline Skewness & 0.790341 & -0.16929 & 0.555806 & -0.50269 & 1.400595 & 1.865961 \\
\hline Kurtosis & 3.623515 & 2.074675 & 1.776664 & 2.164803 & 4.062451 & 6.401537 \\
\hline Jarque-Bera & 3.007633 & 1.011317 & 2.846073 & 1.779532 & 9.349445 & 26.56011 \\
\hline Probability & 0.22228 & 0.603108 & 0.240981 & 0.410752 & 0.009328 & 0.000002 \\
\hline Observations & 25 & 25 & 25 & 25 & 25 & 25 \\
\hline
\end{tabular}

*Sources Eviews

The above table prescribed the descriptive statistics result and all of the variables annually average return SSE (2213.507), M2 (160.1618), GDP (3981.509), FDI 
(3.339566), BOT (3.399398) and LI (6.0892) positive standard deviation. Skewness values of SSE, GDP, BOT, and LI are shows positives and have the long right tail, and the contrary is M2 and FDI, which shows long left rear. The values of kurtosis of M2, GPD and FDI are lying amongst 0-3 except SEE, BOT and LI it's behaved toward platy kurtas normality distribution. The amount of SEE, BOT and LI are above three it indicates that values are anticipated nearby means and respites of variables behave a high peaked value of leptokurtic. The above similarities also find the study of Javed and Hassan (2009). According to the Jarque-Bera statistic confirmed the variables are standard distribute.

\begin{tabular}{|l|c|c|c|c|c|c|}
\hline \multicolumn{7}{|l|}{ Table 4. Correlation Matrix of SEE } \\
\hline & CLOSE & CLNM2 & CLNLI & CLNFDI & CLNGDP & CLNBT \\
\hline CLOSE & 1 & & & & & \\
\hline CLNM2 & 0.974777 & 1 & & & & \\
\hline CLNLI & 0.918284 & 0.900985 & 1 & & & \\
\hline CLNFDI & 0.30939 & 0.333907 & 0.431858 & 1 & & \\
\hline CLNGDP & 0.971155 & 0.997985 & 0.911868 & 0.359872 & 1 & \\
\hline CLNBT & 0.463826 & 0.429379 & 0.333067 & 0.349907 & 0.432371 & 1 \\
\hline
\end{tabular}

The above table shows the correlation between different variables. The SEE have a perfect positive relationship with all independent variables. M2 have a strong positive relationship with all variables except FDI and BOT, which indicates a moderate positive correlation according to fuzzy firm linear rules. LI strong positive correlation with all variables but reasonable with FDI and BOT. FDI has a strong relationship with all variables; however, moderate correlation with M2, LI and BOT. GDP indicates a strong relationship with all variables but moderate with FDI and BOT. BOT shows moderate positive

Table 5. Multiple Regression Analysis of Shanghai Stock Exchange

\begin{tabular}{|l|c|c|c|c|}
\hline \multicolumn{1}{|c|}{ Variable } & Coefficient & Std. Error & t-Statistic & Prob. \\
\hline$\Delta$ LNGDP & $-1.151044 * * *$ & 0.644082 & -1.787108 & 0.0899 \\
\hline$\Delta$ LNBOT & $0.328886 * *$ & 0.146481 & 2.245246 & 0.0368 \\
\hline$\Delta$ LNFDI & -0.520666 & 0.432577 & -1.203638 & 0.2435 \\
\hline$\Delta$ LNLI & $2.019104 *$ & 0.56314 & 3.585437 & 0.002 \\
\hline$\Delta$ LNM2 & $2.997688 * *$ & 1.079687 & 2.776442 & 0.012 \\
\hline
\end{tabular}




\begin{tabular}{|l|c|l|c|c|}
\hline $\mathrm{C}$ & 0.177472 & 0.092381 & 1.921097 & 0.0699 \\
$\mathrm{R}^{2}$ & 0.972527 & & Mean dependent var & -0.25278 \\
\hline Adjusted R-squared & 0.965297 & & S.D. dependent var & 1.664305 \\
\hline S.E. of regression & 0.31004 & & Akaike info criterion & 0.701333 \\
\hline Sum squared resid & 1.826373 & & Schwarz criterion & 0.993864 \\
\hline Log-likelihood & -2.766667 & & F-statistic & 134.5157 \\
\hline Durbin-Watson stat & 1.829732 & & \multicolumn{2}{|c|}{ Prob (F-statistic) } \\
\hline
\end{tabular}

Annotation: dependent variable is SEE (least squares estimation) $* * *$ significant $10 \%$ ** significance $5 \% *$ significance $1 \%$

The above table presented the result of a regression analysis of the Chinese stock market (SSE) with macroeconomic variables. Our result shows all variables are statistically significant relation with GDP except FDI variable. The coefficient of GDP is statistically negative $10 \%$ at the level of significant the relationship between the stock price, and GDP is the negative sign, and $\mathrm{H}_{1}$ is accepted. The coefficient of BOT is statistically significant 5\% at the level, and $\mathrm{H}_{2}$ is accepted, but the FDI coefficient is insignificant at the level here $\mathrm{H}_{3}$ is rejected. LI coefficient is statistically significant at a level of $1 \%$, and $\mathrm{H}_{5}$ is accepted. The coefficient of $\mathrm{M} 2$ is the statistical significance of $5 \%$ at the level, and $\mathrm{H}_{6}$ are accepted. The coefficient assessment determined (R2) is 97.25, which indicate of $97.25 \%$ of changes (variation) in stock market causes of GDP, BOT, LI and M2. The F-statistics value is 134.5157 . Indicate significance $1 \%$ at a level which shows that the models are better appropriate. This similarity is also finding in the study of Mohsinet al. (2019).

\section{Table 6. Breusch-Godfrey Serial Correlation LM Test}

\begin{tabular}{|l|c|l|l|}
\hline F-statistic & 0.50388 & Prob. F $(2,17)$ & 0.6129 \\
\hline Obs*R-squared & 1.399063 & Prob. Chi-Square(2) & 0.4968 \\
\hline
\end{tabular}

The above table results indicate that the P-value 0.6129 (61\%) which is higher than 5\% ( $\mathrm{P}>0.05)$ which means that we can't reject the $\mathrm{H} 0$ hypothesis for no presence of serial correlation.

$$
\begin{aligned}
\boldsymbol{H}_{0} & =\text { there is no serial correlations. } \\
\boldsymbol{H}_{\boldsymbol{I}} & =\text { there is serial correlations. }
\end{aligned}
$$




\begin{tabular}{|l|r|l|l|}
\hline \multicolumn{4}{|l|}{ Table 7. Heteroskedasticity Test: ARCH } \\
\hline F-statistic & 0.024777 & Prob. F(1,22) & 0.8764 \\
\hline Obs*R-squared & 0.026999 & Prob. Chi-Square(1) & 0.8695 \\
\hline
\end{tabular}

$$
\begin{aligned}
& \boldsymbol{H}_{I}=\text { there is heteroskedasticity. } \\
& \boldsymbol{H}_{0}=\text { there is no heteroskedasticity. }
\end{aligned}
$$

In the above table Heteroskedasticity ARCH test shows that F-statistics value is 0.024 with $87 \%$ of probability which shows clearly that there is no heteroskedasticity means to accept $\mathrm{H}_{0}$.

Normality Test for Residuals:

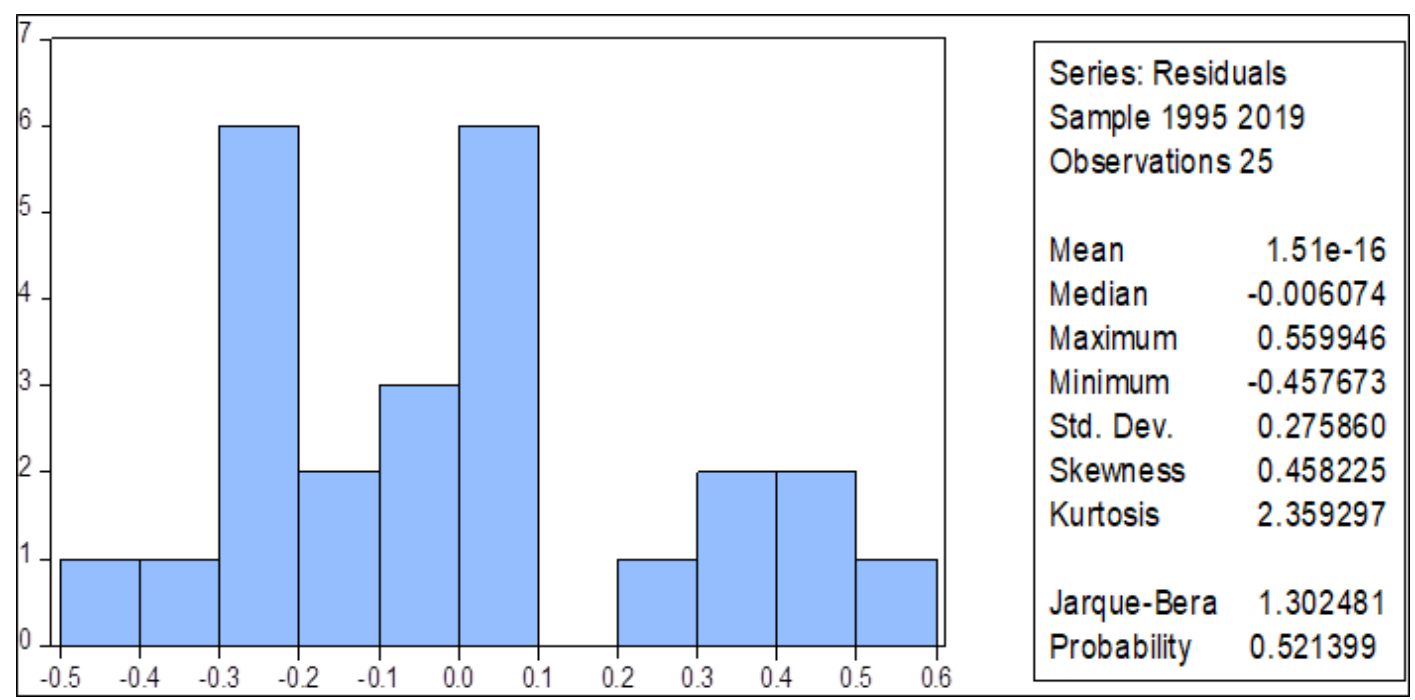

The above Graph presents the test of normality Residuals. The value of JarqueBera is 1.302481 , with the consisting probability value of $52 \%$, which is higher than $5 \%$ at the level of significance. So that normality distribution of null hypothesis cannot be excluded; it is the statement of better regression as Muriu and Ouma (2014). The JarqueBera result shows that the error terms are standard distribute through. This normality distribution similarity also find in Wadhwa and Keswani (2019).

\begin{tabular}{|c|c|c|c|c|c|c|}
\hline \multicolumn{1}{|c|}{ Table 8. Descriptive Statistics of KSE } \\
\hline & KSE & Li & GDP & FDI & M2 & BOT \\
\hline Mean & 15851.64 & 11.4108 & 890.5387 & 1.202881 & 50.47124 & -5.18336 \\
\hline Median & 9556.61 & 10.5 & 908.0951 & 0.892862 & 51.48117 & -5.83639 \\
\hline Maximum & 47806.97 & 20 & 1482.403 & 3.668323 & 58.86769 & 1.03367 \\
\hline Minimum & 945.24 & 5.75 & 454.2761 & 0.382827 & 38.5947 & -12.476 \\
\hline
\end{tabular}




\begin{tabular}{|c|c|c|c|c|c|c|} 
Std. Dev. & 15967.86 & 3.85457 & 372.2999 & 0.885232 & 5.616601 & 3.726677 \\
\hline Skewness & 0.754475 & 0.449113 & 0.19117 & 1.697848 & -0.3031 & -0.05011 \\
\hline Kurtosis & 1.992246 & 2.541467 & 1.494933 & 4.829729 & 2.338615 & 2.182018 \\
\hline Jarque-Bera & 3.429685 & 1.059439 & 2.511886 & 15.49861 & 0.838439 & 0.707436 \\
\hline Probability & 0.179992 & 0.58877 & 0.284807 & 0.000431 & 0.65756 & 0.702073 \\
\hline Observations & 25 & 25 & 25 & 25 & 25 & 25 \\
\hline
\end{tabular}

The above table prescribed the descriptive statistics result and all of the variable annually average return KSE (15851.64), M2 (50.47124), GDP (890.5387), FDI (1.202881), BOT (-5.18336) and LI (11.4108) positive standard deviation. Skewness values of KSE, GDP, FDI, and LI are shows positives and have a long right tail, and the contrary is M2 and BOT, which shows long left rear. The Values of kurtosis of KSE, M2, GPD, LI and BOT are lying amongst 0-3 except FDI it's behaved toward platy kurtic lower peak. The value of FDI, which is above three it indicates that values are anticipated nearby means and respites of the variable act a high peaked value of leptokurtic. The above similarities also find the study of javed and Hasan (2009) Except FDI all data are distributed normally. According to the Jarque-Bera statistic confirmed the variables are normal to distribute.

Table 9. Correlation Matrix of KSE

\begin{tabular}{|l|l|l|l|l|l|l|}
\hline & C LNKSE & C LNGDP & C LNFDI & C LNLI & C LNM2 & C LNBOT \\
\hline CLNKSE & 1 & & & & & \\
\hline CLNGDP & -0.54145 & 1 & & & & \\
\hline CLNFDI & -0.36198 & 0.018522 & 1 & & & \\
\hline CLNLI & 0.36806 & -0.03912 & 0.028631 & 1 & & \\
\hline CLNM2 & -0.25332 & -0.07538 & 0.523521 & 0.011278 & 1 & \\
\hline CLNBOT & -0.14386 & -0.15399 & -0.20199 & -0.30238 & -0.26263 & 1 \\
\hline
\end{tabular}

The above table shows the correlation between different variables. The KSE has a perfect positive relationship with all independent variables. GDP has a moderate negative correlation with FDI, positive with LI and weak negative with M2 and BOT according to shaky linear rule. FDI correlation is weak negative with M2 and BOT but faint positive with GDP and moderate positive with LI via fuzzy firm rules. LI has a weak negative correlation with M2, BOT and GDP. M2 have weak negatively correlated 
by BOT and GDP but faint positive with LI, strong positive with FDI. BOT has a weak negative correlation with GDP, M2, and FDI, however, moderate negative with LI.

\begin{tabular}{|c|c|c|c|c|}
\hline \multicolumn{6}{|c|}{ Table 10. Results of Multiple Regression Analysis of Pakistan Stock Market } \\
\hline Variable & Coefficient & Std. Error & t-Statistic & Prob. \\
\hline CLNGDP & $-0.583369^{*}$ & 0.145814 & -4.000768 & 0.0008 \\
\hline CLNFDI & $-0.050554^{* * *}$ & 0.028002 & -1.805382 & 0.0869 \\
\hline CLNLI & $0.091615^{* * *}$ & 0.049833 & 1.838444 & 0.0817 \\
\hline CLNM2 & -0.251546 & 0.203043 & -1.238876 & 0.2305 \\
\hline CBOT & -0.019675 & 0.011656 & -1.687998 & 0.1078 \\
\hline C & 0.086181 & 0.012203 & 7.062142 & 0 \\
\hline R-squared & 0.618125 & & Mean dependent var & 0.061406 \\
\hline Adjusted R-squared & 0.517632 & & S.D. dependent var & 0.073351 \\
\hline S.E. of regression & 0.050944 & & Akaike info criterion & -2.9106 \\
\hline Sum squared resid & 0.049311 & & Schwarz criterion & -2.61807 \\
\hline Log-likelihood & 42.38255 & & F-statistic & 6.150911 \\
\hline Durbin-Watson stat & 2.028895 & & Prob(F-statistic) & 0.001499 \\
\hline
\end{tabular}

Annotation: dependent variable is KSE (least squares estimation) $* * *$ significant $10 \% * *$ significance $5 \% *$ significance $1 \%$

The above table presents the results of regression analysis of Pakistan stock market (KSE) with macroeconomic variables. Our result shows GDP is negative statistical significance $1 \%$ at level; the FDI is negative significance $10 \%$ at the level. LI is positively significant at $10 \%$ at the level. But M2 and BOT is insignificant. The coefficient assessment determined (R2) is 0.618125 which indicate of $61 \%$ of changes (variation) in stock market causes of GDP, BOT, FDI, LI and M2. The F-statistics value is 6.150911 , which are $1 \%$ at a level significantly as well as indicates models are better appropriate. This similarity is also finding in the study of Naseem et al. (2019).

\begin{tabular}{|c|c|c|c|}
\hline Table 11. Breusch-Godfrey Serial Correlation LM Test: \\
\hline F-statistic & 0.170631 & Prob. F(2,17) & 0.8446 \\
\hline Obs*R-squared & 0.491981 & Prob. Chi-Square(2) & 0.7819 \\
\hline
\end{tabular}

The beyond table result shows that P-value0.8446 (84\%), which is greater than $5 \%$ ( $\mathrm{P}>0.05)$ which means that we can't reject the null hypothesis for there is no serial correlation. 
$\boldsymbol{H}_{\boldsymbol{0}}=$ have not serial correlation.

$\boldsymbol{H}_{1}=$ have serial correlation .

\section{Table 12. Heteroskedasticity Test: ARCH}

\begin{tabular}{|l|c|c|c|}
\hline F-statistic & 3.143441 & Prob. F(1,22) & 0.0901 \\
\hline Obs*R-squared & 3.000487 & Prob. Chi-Square(1) & 0.0832 \\
\hline
\end{tabular}

$\boldsymbol{H}_{0}=$ there is no heteroskedasticity.

$\boldsymbol{H}_{1}=$ there is heteroskedasticity.

In the above table, Heteroskedasticity ARCH test shows that F-statistics value is 3.143441 with $9 \%$ of probability which shows clearly that there is no heteroskedasticity means to accept $\mathrm{H}_{0}$

\section{Normality Test for Residuals}

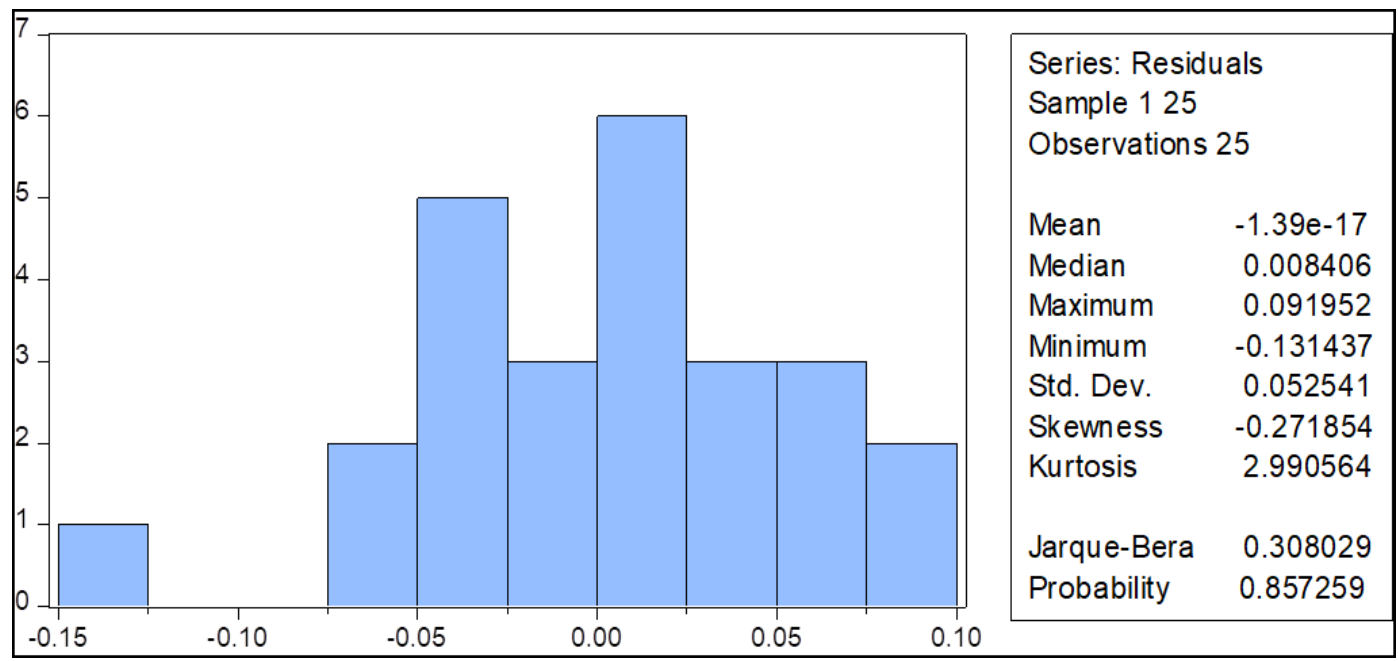

The above Graph presents the test of normality Residuals. The value of JarqueBera is 0.308029 by the consisting probability valued of $86 \%$, which is greater than the $5 \%$ level of significance. So the normality distribution of null hypothesis cannot be excluded; it's the statement of better regression as Muriu and Ouma (2014) The JarqueBera result shows that the error terms are normally distributed through. This normality distribution similarity also find in Wadhwa and Keswani (2019) 


\section{CONCLUSION AND SUMMARY}

An exertion has prepared on this study to scrutinize; however, essential macroeconomic factors impact both stock markets of China and Pakistan. The key objectives of the study to examine the relationships among Karachi Stock Exchange (KSE-100) and Shanghai Stock Exchange (SSE) in China and Pakistan. Utilizing time series annually data from the periods of 1995 to 2019 with the nominated macroeconomic variables, Gross Domestic Product (GDP), Balance of Trade (BOT), Foreign Direct investments (FDI), Lending interest (LI) and Broad Money Supply (M2). For the accurate and appropriate outcomes used the serial correlation and heteroskedasticity with normality test for residuals used the correlation matrix for all variables to examine the serial correlations so that outcomes of the study exactly understood. The multiple regression models indicate that the Karachi Stock Exchange (KSE-100 index) and a Shanghai Stock Exchange (SSE) macroeconomic variable means the dependent and independent variable have casual relationships. The study result indicates the GDP is the negative significance with both stock exchange it means that not have a significance positively relationship between the GDP growth rates and stock market returns while the increase in productions level lead to increases in profitability and earning the response from the stock market will be positive. The balance of trade shows the relationship positive significant with SSE. In contrast, an insignificant impact in KSE-100 index due to deficit trade balance term of FDI relation is insignificant with SSE. Still, negative significant with KSE so, the greater volume of trade and FDI may be attracted. Money supply ha a significant impact on SEE but no relation means a show with KSE. Lending interest is impacted significantly with SSE and KSE stock exchanges means that Increases in the rate of interest result will be push up stock price companies in the stock market. With the increasing awareness and information of these types of relationships, investors are capable to enhanced investment decision making meanwhile have the essentials information on the tendency and predict of altered economies particularly the possible growth of the stock market. It is determined that relationships have existed amongst macroeconomic variables and both stock markets on the sources of this 
relationship forecasting can be prepared through this study. The increasing interest rate of the bank is not favour of a dynamic stock market which causes of effect on the stock exchange as well as on economy, especially on Pakistan. This study is supportive for foreign and domestic investors hence to investment in both stock exchange.

\section{REFERENCES}

Adam, A. M., \& Tweneboah, G. (2008). Macroeconomic factors and stock market movement: Evidence from Ghana. Available at SSRN 1289842.

Ahmed, H., Ehsanullah, M., \& Mahmood, I. (2011). Exchange Rate Volatility \& Macroeconomic Variables in Pakistan. Business management dynamics, 11-22.

Ahmed, T., Ahmed, M., Ahmed, Z., lqbal, N., \& Raza, (2012). The Role of FDI on Stock Market Development: The Case of Pakistan. Journal of Economics and Behavioral Studies, Vol. 4, No. 1, 26-33.

Ali, L., Shahbaz, M., \& nadeem. (2008). Stock market development and economic growth: International Research. Journal of Finance and Economics, 1450-2887.

Al Shabib, D. K., \& Al-Abedallat, A. Z. (2012). Impact of the investment and gross domestic product on the Amman Stock Exchange index. Investment Management and Financial Innovations, 130-136.

Ainous, R. (2018). Macroeconomic, Income Inequality, and Poverty Relationship: A Review of Research Perspectives. The Review of Black Political Economy, 45(2), 123-146.

Ayea, G. C., Gupta, R., Miller, S. M., \& Simo-Kengne, B. D. (2015). Time-Varying Effects of Housing and Stock Returns on U.S. Consumption. The Journal of Real Estate Finance and Economics, 339-354.

Barakat, M. R., Elgazzar, S. H., \& Hanafy, K. M. (2016). Impact of Macroeconomic Variables on Stock Markets: Evidence from Emerging Markets. International Journal of Economics and Finance, 8(1), 195-207.

Barbiero, O., Farhi, E., Gopinath, G., \& Itskhoki, O. (2019). The macroeconomics of border taxes. NBER Macroeconomics Annual, 33(1), 395-457.

Bårdsen, G., Jansen, E. S., Eitrheim, Ø. \& Nymoen, R. (2005). The econometrics of macroeconomic modelling. OUP Oxford.

Chen, N. F., Roll, R., \& Ross, S. (1986). Economic Forces and the Stock Market. The Journal of Business, vol. 59, issue 3, 383-403.

Chirichiello, G. (2000). Intertemporal Macroeconomic Models, Money and Regional Choice. Springer.

De Loecker, J., Eeckhout, J., \& Unger, G. (2020). The rise of market power and the macroeconomic implications. The Quarterly Journal of Economics, 135(2), 561644.

Den Butter, F. A. G. (1991). Macroeconomic modelling and the policy of restraint in the Netherlands. Economic Modelling, 8(1), 16-33.

Driehuis, W., Fase, M. M. G., \& Den Hartog, H. (Eds.). (2014). Challenges for macroeconomic modelling. Elsevier.

Fama, E. F. (1970). Efficient Capital Markets: A Review of Theory and Empirical Work. The Journal of Finance, Vol. 25, No. 2, 383-417.

FAMA, E. F. (1981). Stock returns, real activity, inflation and money. AMERICAN ECONOMIC REVIEW, VOL. 71 NO. 4, 545-565. 
Fratzscher, M., \& Straub, R. (2010). Asset Prices, News Shocks and the Current Account. CEPR Discussion Papers 8080, C.E.P.R. Discussion Papers.

FAMA, E. (1990). Stock Returns, Expected Returns and Real Activity. THE JOURNAL OF FINANCE, VOL. XLV, NO. 4, 1089-1108.

Fontana, G., \& Setterfield, M. (Eds.). (2016). Macroeconomic theory and macroeconomic pedagogy. Springer.

Gay, \& D, R. (2016). Effect of Macroeconomic Variables on Stock Market Returns for Four Emerging Economies: Brazil, Russia, India, and China. International Business \& Economics Research Journal, 119-126.

Gilani. U. J., Nawaz, M. M., \& Nazir, S. (2010). Relationship between economic growth and stock market development. . African Journal of Business Management, 4(16), 3473-3479.

Goh, K. L., \& Chong, C. (2003). Linkages of economic activity, stock prices and monetary policy the case of Malaysia. International Journal of Educational Management, 159-184.

Harasheh, M., \& Libdeh, H. A. (2011). Testing for correlation and causality relationships between stock prices and macroeconomic variables the case of Palestine securities exchange. International Review of Business Research Papers, 141154.

Hairault, J. O., \& Kempf, H. (Eds.). (2013). Market imperfections and macroeconomic dynamics. Springer Science \& Business Media.

Hall, S. G., \& Henry, S. G. (2014). Macroeconomic modelling. Elsevier.

Henry, K. (2013). Macroeconomic policy challenges in the Asian century. The Economic and Labour Relations Review, 24(2), 150-160.

Hogan, K., Robert, D. J., \& Melvin, M. (1991). Trade Balance News and Exchange Rates: Is There a Policy Signal. Journal of International Money and Finance, S90-S99.

Javed, M. T., \& Hasan, A. (2009). An Empirical Investigation of the Causal Relationship among Monetary Variables and Equity Market Returns. Lahore Journal of Economics 14, journl: v: 14, 115-137.

k, G., \& Pooja, J. (2017). THE IMPACT OF MACROECONOMIC INDICATORS ON INDIAN STOCK PRICES: AN EMPIRICAL ANALYSIS. Studies in Business and Economics, no. 12(1)/2017, 61-78.

KOCHIN, L. A., \& KOCHIN, M. J. (1972). MONEY AND STOCK PRICES: THE CHANNELS OF INFLUENCE. Journal of Finance, 231-249.

Levine, R., \& Beck, T. (2004). Stock markets, banks, and growth Panel evidence. Journal of Banking \& Finance 28 (2004) 423-442, 423-442.

LEVINE, R., \& KING, R. (1993). FINANCE AND GROWTH: SCHUMPETER MIGHT BE RIGHT. Quarterly Journal of Economics, Vol. 108(3), 717-737.

MAHMOOD, T., \& HUSAIN, F. (2001). The Stock Market and the economy in pakistan. The Pakistan Development Review, 107-114.

Martin, S. (2012). The impact of money supply on stock prices and stock bubbles. https://mpra.ub.uni-muenchen.de/40919/MPRA Paper No. 40919, 1-17.

Maskay , B. (2007). Analyzing the Effect of Change in Money Supply on Stock. The Park, Vol. 15. 72-97.

Mehrara, M. (2006). The relationship between stock market and macroeconomic variables. Iranian Economic Review (IER), 137-148.

Mittal, R., \& Pal, K. (2011). Impact of macroeconomic indicators on Indian capital markets. The Journal of Risk Finance, 84 - 97.

Mohsin, M., Amjad, F., salamat, s., Rehma, M. Z.-u., Fu, G. L., \& naseem, s. (2019). 
Impact of macroeconomic variables on Exchange rate: an evidence from Pakistan. https://link.springer.com/conference/icoae, 325-333.

Mukit, M. a. (2012). Effects of Interest Rate and Exchange Rate on Volatility of Market Index at Dhaka Stock Exchange. Journal of Business and Technology (Dhaka), Vol. 7, Issue 2, 1-18.

Mussa, M., \& Savastano, M. (1999). The IMF approach to economic stabilization. NBER macroeconomics annual, 14, 79-122.

Naseem, s., Fu, G. L., ThiLan, V., Mohsin, M., \& Zia-Ur-Rehman, M. (2019). Macroeconomic Variables and the Pakistan Stock Market: Exploring Long and Short-Run Relationships. Pacific Business Review International, Volume 11 Issue 7, 62-72.

Nelson, D. B. (1996). Modelling stock market volatility changes. Modelling Stock Market Volatility: Bridging the Gap to Continuous Time.

Ouma, N. W., \& Muriu, P. (July 2014). THE IMPACT OF MACROECONOMIC VARIABLES ON STOCK MARKET RETURNS IN KENYA. International Journal of Business and Commerce, Vol. 3, No.11, 01-31].

Park, S. (1997). Rationality of Negative Stock-Price Responses to Strong Economic Activity. Financial Analysts Journal, 52-56.

Perkins, J. (1997). Budget deficits and macroeconomic policy. Springer.

Pflueger, C., Siriwardane, E., \& Sunderam, A. (2020). Financial market risk perceptions and the macroeconomy. The Quarterly Journal of Economics, 135(3), 14431491.

REILLY, F. k., \& BROWN, K. c. (2003). Investment Analysis \& Portfolio Management (7th ed.). South-Western Cengage Learning: Mason Ohio, USA.

ROSS, S. A. (1976). The Arbitrage Theory of Capital Asset Pricing. Journal of economic theory, 341-360.

Schism, D. c., \& Aggarwal, R. (1998). Asymmetric impact of trade balance news on asset prices. International Financial Markets, Institutions \& Money, 83-100 .

Schmukler, S., Klingebiel, D., \& Claessens, S. ((2001). FDI and Stock Market Development Complements or Substitutes. Joint Conference of the IDB and the World Bank The FDI Race: Who Gets the Prize? Is it Worth the Effort? , 1-52.

Schirm, D. C., \& Aggarwal, R. (1992). Balance of Trade Announcements and Asset Prices: Influence on Equity. Journal of International Money and Finance, 80-95.

Simo-Kengne, Miller, S., Gupta, R., \& Aye, G. (2015). Time-Varying Effects of Housing and Stock Returns on U.S. Consumption. The Journal of Real Estate Finance and Economics, 339-354.

Steven, Hayworth, Dewan, \& Abdullah. (1993). Macroeconometrics of Stock Price Fluctuations. Journal of Business and Economics, , 50-67.

Straub, R., \& Fratzscher, M. (2009). Asset Prices And Current Account Fluctuations In G7 Economies. IMF Staff Papers, 633-654.

Trivoli, G. W., \& Bulmash, S. B. (1991). Time-lagged interactions between stockprices and selectedeconomic variable. Journal of Portfolio Management, 61-67.

Uddin, M. G., \& Alam, M. M. (2009). Relationship between interest rates and stock prices: empirical evidence from developed and developing countries. International Journal of Business and Management, 43-50.

Walter, J. (1989). MONETARY AGGREGATES: A USER'S GUIDE . FRB Richmond Economic Review, Vol. 75, , 20-28.

Wilson, P., \& Peebles, G. (1996). The Singapore Economy. . Cheltenham, : Edward Elgar. 
BIBLIOGRAPHY Wadhwa, B., \& Keswani, S. (2019). Evaluating the Impact of Macroeconomic Variable on Indian Stock Market. International Journal of Engineering and Advanced Technology (IJEAT, Volume-8 Issue-6, 4427-4434.

Yu, Q., \& Mookerjee, R. (1997). Macroeconomic variables and stock prices in a small open economy: The case of Singapore. Pacific-Basin Finance Journal 5, Vol. XVIII, NO.2, 377-388.

Zahra, S. A., Neubaum, D. O., \& Hayton, J. (2020). What do we know about knowledge integration: Fusing micro-and macro-organizational perspectives. Academy of Management Annals, 14(1), 160-194 